\title{
TU/e EnNHOUN

\section{Novel concept for an integrated optical waveguide isolator for picosecond pulse operation}

\section{Citation for published version (APA):}

Heck, M. J. R., Bente, E. A. J. M., Barbarin, Y., Lenstra, D., \& Smit, M. K. (2007). Novel concept for an integrated optical waveguide isolator for picosecond pulse operation. In Proceedings of the 2007 European Conference on Lasers and Electro-Optics and the International Quantum Electronics Conference (CLEO E-IQEC 2007) 17-22 June 2007, Munich, Germany (pp. CF8_2-1/1). Institute of Electrical and Electronics Engineers. https://doi.org/10.1109/CLEOE-IQEC.2007.4386277

DOI:

10.1109/CLEOE-IQEC.2007.4386277

Document status and date:

Published: 01/01/2007

\section{Document Version:}

Publisher's PDF, also known as Version of Record (includes final page, issue and volume numbers)

\section{Please check the document version of this publication:}

- A submitted manuscript is the version of the article upon submission and before peer-review. There can be important differences between the submitted version and the official published version of record. People interested in the research are advised to contact the author for the final version of the publication, or visit the $\mathrm{DOI}$ to the publisher's website.

- The final author version and the galley proof are versions of the publication after peer review.

- The final published version features the final layout of the paper including the volume, issue and page numbers.

Link to publication

\section{General rights}

Copyright and moral rights for the publications made accessible in the public portal are retained by the authors and/or other copyright owners and it is a condition of accessing publications that users recognise and abide by the legal requirements associated with these rights.

- Users may download and print one copy of any publication from the public portal for the purpose of private study or research.

- You may not further distribute the material or use it for any profit-making activity or commercial gain

- You may freely distribute the URL identifying the publication in the public portal.

If the publication is distributed under the terms of Article 25fa of the Dutch Copyright Act, indicated by the "Taverne" license above, please follow below link for the End User Agreement:

www.tue.nl/taverne

Take down policy

If you believe that this document breaches copyright please contact us at:

openaccess@tue.nl

providing details and we will investigate your claim. 


\title{
Novel Concept for an Integrated Optical Waveguide Isolator for Picosecond Pulse Operation
}

\author{
M.J.R. Heck ${ }^{1}$, E.A.J.M. Bente ${ }^{1}$, Y. Barbarin ${ }^{1}$, D. Lenstra ${ }^{2}$ and M.K. Smit ${ }^{1}$ \\ 1. COBRA Research Institute, Technische Universiteit Eindhoven, P.O. 513, 5600 MB Eindhoven, the Netherlands \\ 2. Dept. of Electrical Engineering, Mathematics and Computer Science, Technische Universiteit Delft, the Netherlands
}

Using current photonic integration technology different active and passive optical components can be combined on a single chip. The operation of active components, such as semiconductor optical amplifiers (SOAs) and in particular lasers, is disturbed by optical feedback down to the $-50 \mathrm{~dB}$ level. Such feedback can be caused by reflections of the device output signal on components further downstream in the circuit. Thus some form of integrated optical isolation is required to prevent destabilization of active devices.

Most attempts to obtain integrated optical isolators are based on magneto-optic effects [1] to break the symmetry between the forward and backward propagation direction in a waveguide. Such work is however targeted towards a general purpose optical isolation. In many practical applications the forward traveling signal is a train of short optical pulses such as those generated by a mode-locked laser. The feedback, which is the backward traveling signal, is typically amplified spontaneous emission (ASE) from another active component or a reflection of the forward traveling signal. In both cases the backward traveling signal will be lower in peak power by about two to three orders of magnitude. This fact can be utilized to achieve optical isolation.

In this paper we propose the use of a concatenated array of SOAs and saturable absorbers (SAs, reversely biased SOAs) as an integrated optical waveguide isolator for picosecond pulses (Fig. 1(a)). The saturation energy of the SA is smaller than the saturation energy of the SOA. An asymmetry in the forward and backward gain, i.e. isolation, can be created by operating the SOA/SA pairs at a point where the pulse energy of the forward propagating signal can saturate (open) the SAs as opposed to the backward propagating signal, which has a lower power or pulse energy. When the forward traveling signal opens one of the SAs, the backward traveling signal is not attenuated by that SA. To ensure that all parts of the backward going signal are attenuated, multiple SOA/SA pairs are used. As the forward signal is pulsed this configuration ensures that the backward traveling signal always propagates through several unsaturated (closed) SAs. The periodicity of the pairs of the SOA/SA pairs can be optimized for a specified pulse rate.

Simulations of these devices have been performed using SOA and SA rate equation models as presented in [2], extended with an ASE term. The parameters used are valid for the InP/InGaAsP material. Figure 1(b) shows the simulated isolation for a $2 \mathrm{~mm}$ device, consisting of ten SOA/SA pairs. Simulated isolation levels are $20 \mathrm{~dB}-35 \mathrm{~dB}$ for the devices with the longer SAs. With typical reflection levels of $0.1 \%$ to $1 \%$ on chip, this keeps the feedback below $-50 \mathrm{~dB}$. As such the device is a very promising option for integration with a MLL. Furthermore generated peak ASE levels are low, below $15 \mu \mathrm{W}$ in both directions, for the given injection currents. A first series of experimental devices has been realized and we expect to be able to present first results.

(a)

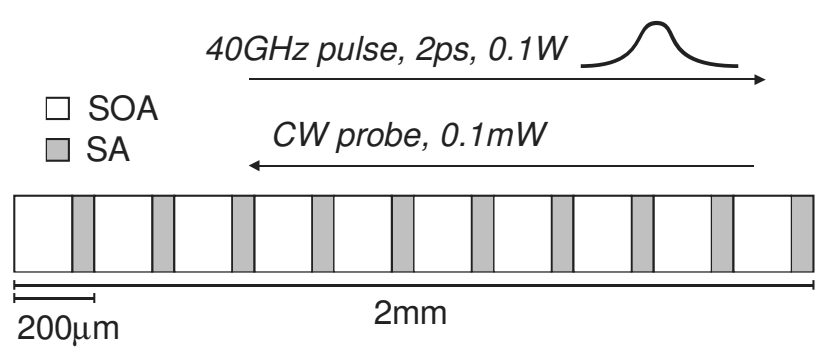

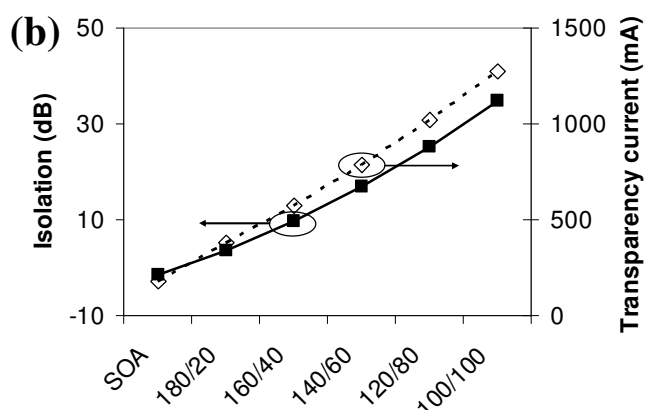

Fig. 1(a) Simulated device configurations: each SOA/SA pair has a combined length of $200 \mu \mathrm{m}$, with a varying length ratio. The forward signal is a $40 \mathrm{GHz}$ train of pulses with a duration of $2 \mathrm{ps}$ and a peak power of $0.1 \mathrm{~W}$, typical for integrated MLLs [2]. The backward signal is a $0.1 \mathrm{~mW}$ continuous wave probe signal.

(b) Simulated absorption (isolation) for different device configurations (SOA/SA lengths are given ( $\mu \mathrm{m}$ ), $2 \mathrm{~mm} \mathrm{SOA} \mathrm{for}$ reference) of the backward probe signal when the device is operated at transparency for the forward signal. The total device injection current (i.e. for the ten SOAs) needed to obtain transparency is shown. The SA recovery time is $5 \mathrm{ps}$.

\section{References}

1. W. van Parys et al., "Transverse magnetic mode nonreciprocal propagation in an amplifying AlGaInAs/InP optical waveguide isolator," Appl. Phys. Lett. 88, 071115 (2006).

2. M.J.R. Heck et al., "Simulation and design of integrated femtosecond passively mode-locked semiconductor ring lasers including integrated passive pulse shaping components,” IEEE J. Sel. Top. Quant. Electron. 12, 265-276 (2006). 